\title{
Using design for upgrading in the fashion industry
}

Patrik Aspers*,**

\begin{abstract}
The purpose of the article is to analyze upgrading by looking at the design of fashion garments. To that end, I use the theoretical concept of contextual knowledge to understand the problems faced by firms, and their staff, that want to upgrade through design. Contextual knowledge combines a general knowledge of fashion with the lifeworld that actors use for interpretation of fashion. Lifeworld is a notion which refers to what is taken for granted. Producers and consumers in the global fashion industry live in different lifeworlds. The text discusses upgrading strategies of garment manufacturers, drawing on unique empirical material. It provides a theoretical tool for analyzing culturally primed production in a global setting.
\end{abstract}

Keywords: Knowledge, upgrading, design, fashion, market

JEL classifications: F14, D83, L14, L67, O31

Date submitted: 29 March 2008 Date accepted: 5 June 2009

\section{Introduction}

Garment production is a typical example of a global industry. Production takes place in developing countries, while design and marketing are carried out or managed in main offices located in developed countries, often in global cities (cf. Sassen, 2001, xx) where fashion trends are set, and where fashion designers who try to be 'cool' by rubbing their shoulders with 'cool' people who hang out in 'cool' places Hauge (2007, III, IV, 10-19). This means that consumption is separated from production not only by a market interface, but also by physical distance, and often by other forms of distance, such as religious, economic, linguistic, developmental and cultural. We can assume that these differences have consequences. How, for example, does the distance between marketing and design locations, on the one hand, and production locations, on the other, influence the design process?

If one looks at the manufacturing of garments, the industry is located in many countries across the globe. However, the value-creating activities of branding, design and marketing are not at all 'global'; the value-adding activities are still protected areas of firms, since this is the way to make big money in the industry (Bonacich and Applebaum, 2000; Bair and Gereffi, 2003, 149; Hassler 2003, 523). Consequently, the main players in cultural industries are concentrated in space (Power, 2002). Moreover, the different fashion consumer markets are still largely national, and may be extremely local, sometimes only localized within an area of a few blocks, as in Tokyo (Kawamura, 2006). The economic importance of design, marketing and, more generally, 'aesthetic'

\footnotetext{
*Max Planck Institute for the Study of Societies, Paulstr. 3, 50676 Cologne, Germany. **Department of Sociology and Score, Stockholm University, 10691 Stockholm, Sweden. email < patrik.aspers@sociology.su.se>
} 
values, however, is likely to increase in the future, reflected by the notions of cultural industries (Power and Scott, 2004), aesthetic economy (Entwistle, 2002) and cultural economy (Du Gay and Pryke, 2000; Amin and Thrift, 2004), as well as that of the knowledge economy (cf. Barry and Slater, 2005). This may lead to yet higher entry barriers in the consumer markets, at the same time as the entry barrier for production, that is, those that suppliers of the garments face, will continue to be relatively low.

The purpose of the article is to analyze upgrading by looking at the design of fashion garments. To address this issue is a way to see the problems and possibilities of upgrading through the means of knowledge, such as design, in contrast to more 'information-based' knowledge of production technology, which often is concentrated in industrial districts (cf. Giuliani, 2007). This article addresses the problem of how to get knowledge across global markets in cultural industries. I use the concept of 'contextual knowledge' (Aspers, 2006b) to explain what firms need to upgrade, which is a 'phenomenological' way to explain how knowledge is connected to place and to power in a global context (Maskell and Malmberg, 2007).

Several studies have shown that knowledge exchange, especially in cultural industries, takes place in markets. Sunley et al. $(2008,678)$ argue, 'that the market plays a key knowledge formation role; the design market is not a narrow channel that only sends flickering price and demand signals but instead acts as a broad, interpersonal and frequently relational channel that carries a great deal of learning and knowledge exchange'. This and other studies (e.g. Kloosterman, 2008) have reported knowledge transfer in different industries, which supports the so-called 'local knowledge spillovers' thesis (cf. Wenting, 2008). These studies, however, report on exchange among people of similar background, but this is 'not' the condition across the production markets in the global fashion industry.

To study knowledge across markets in the global fashion industry, with fewer standards and with less codified knowledge than most other industries (Aspers, 2009), is an especially good case study for the understanding of cultural industries. Secondly, the concept of contextual knowledge contributes to the literature dealing with knowledge, which has not paid enough attention so far to the combination of knowledge and the situation (Swidler and Arditi, 1994, 321). The concept aims to catch what is special about the production of fashion, namely, the 'mysterious' knowledge that people have to possess, often described in terms of 'creativity', 'talent', 'gut-feeling' or 'genius'. Though there are several studies that deal with knowledge, also within economic geography, the discussion is still centered on the distinction between 'tacit' and 'codified' knowledge (Gertler, 2003). These concepts, however, do not explain much about what knowledge is, as they only focus on the individual, and often on her body. The knowledge in this case is 'hidden' or seen as traits (as if it were 'natural'). These notions I cannot fully explain knowledge exchange in, for example, global industries. The notion of contextual knowledge, in contrast, ties the individual's knowledge to interpretations of contexts. This article, draws on empirical research, and with the help of the notion of contextual knowledge, it spotlights the uneven geographies of knowledge.

\section{Upgrading}

What opportunities are open to garment manufacturers in developing countries to enable them to claim a share of the more profitable layers of the production chain? 
Upgrading is perhaps the most obvious route that firms use to improve their situation, though not all firms aim at upgrading. Upgrading has been defined as 'enhancing the relative competitive position of the firm' (Schmitz and Knorringa, 2000, 181), which means - in the case of the garment industry - that firms shift roles and get closer to brand manufacturing and increase the skill content of their activities and/or move into market niches which have entry barriers' which 'insulate' firms from the most fierce competition (Humprey and Schmitz, 2002, 1018; cf. Bair and Gereffi, 2003, 147). Upgrading, especially in the relatively technologically stable garment industry, is a form of vacancy chain process (White, 1970), in which the functions remain the same but the firms are even internationally interchangeable (cf. Gereffi, 1999; Bair and Gereffi, 2002; Palpacuer et al., 2005). Upgrading ought to be understood in the light of the global market economy with fierce competition, not only in relation to the pressure for profit in financial markets (cf. Palpacuer and Parisotto, 2003, 100), but also in relation to the producer markets where firms face consumers (White, 2002).

Upgrading implies economic coordination between the firm and its environment. The literatures on production chains and upgrading acknowledge three ways to coordinate economic activities, including upgrading, markets, hierarchies and networks (Humprey and Schmitz, 2002, 1021), of which the importance of the market has been downplayed. Markets, in contrast to 'innovation networks' (Coe and Bunnell, 2003) and organizational learning within global firms (e.g. Currah and Wrigley, 2004), can be strategically used by retailers to block information to potential competitors, including those emerging from their own set of suppliers. In other words, the 'network' relation between the buying retailers and the selling manufacturers must be seen in the light of the market and its logic of substitutability and competition of manufactures. Not only global buyers, but also political-economic processes, may be entry barriers for manufacturers (Thomsen, 2007).

Firms can upgrade in four different ways. They can upgrade their work processes and their products. A third way of upgrading is to take the knowledge from one sector and make use of it in another (cf. Gereffi, 1999, 51-55; Humprey and Schmitz, 2002, 1020). A fourth way is functional upgrading, which is to move into the more valueadded and, in many cases, more profitable areas of design and marketing with increased skill content. Thus, some manufacturers have upgraded from assembly production to 'full package production', which means that they 'develop the capability to interpret designs, make samples, source the needed inputs, monitor product quality, meet the buyer's price and guarantee on-time delivery' (Gereffi et al., 2005, 92). For manufacturers, the next step on the upgrading ladder is to develop brands of their own.

I will focus on the role of design within firms as a means of upgrading. This topic is not well studied, perhaps because design is so intangible and hard to communicate using language. It has been noted that the literature on upgrading focuses on material conditions (Schmitz and Knorringa, 2000), e.g. 'technology transfer' (Schrank, 2004), and on 'clustering' (Giuliani et al., 2005). To analyze the role of design is not to deny other preconditions of upgrading, namely, information, economic capital and access to global markets (cf. Gereffi et al., 2005, 99-100). One cannot simply say (e.g. Burt, 1992) that the garment manufacturers face an information problem, due to their structural position in the production chain, and that this is the reason why they cannot upgrade, as information is relatively easy to get. Marketing costs for entering a market, for example, may be insurmountable to many firms (cf. Tokatli, 2007a). A complete study on upgrading, however, must account for cultural, economic as well as the 
knowledge aspects. Upgrading through design (e.g. Gereffi, 1999; Skov, 2002, 2003) is related to the way manufacturers learn from their buyers (Schmitz and Knorringa, 2000; Bair and Gereffi, 2002, 37; Knorringa, 2002; Peters et al., 2002; Tokatli and Eldener, 2004; Gereffi et al., 2005). Producers can learn either directly from foreign buyers or indirectly by using them as benchmarks (e.g. Amsden, 2001, 55, 286).

The literature seems to agree that upgrading through design is difficult, and it is rarely observed (Tokatli, 2007a, 57). Tokatli (2007a, 2007b) reports on what are still mostly exceptions that have taken place in certain segments, namely, garmentproducing firms that have managed to achieve functional upgrading so that they design and market their own brands. Upgrading through design is even less likely to take place in India, though as Tewari $(2006,2326)$ argues, 'Indian apparel export ...could, if nurtured well, move the apparel industry to a higher value-added, design-intensive path of upgrading' (my emphasis). But what is so special about upgrading through design? Korzeniewicz (1994) uses the global commodity/value chains approach to analyze the commodity chain driven by Nike. He emphasizes that the chain must be understood in relation to the final consumer market, where the symbolic values of commodities are determined, though this idea is not well reflected in later studies. Korzeniewicz's study indicates that a fashion designer, regardless of where she is located, must 'understand' how commodities get their meaning, but what we lack is an explanation of why upgrading through design is so infrequently observed. Weller (2007) takes up the notions of fashion and knowledge and thereby adds an important component to our understanding of why it is so hard to upgrade in this industry. Her study goes beyond the distinction between tacit and codified knowledge, and stresses how difficult it is to get fashion knowledge across space and time. In this text, the spatial and cultural distances are related to knowledge (cf. Gertler, 2003) by employing the theoretical notion of contextual knowledge to unique empirical material.

\section{Field and methods}

Although the main thrust of this article is theoretical, the arguments presented here are supported by empirical evidence. The empirical research is restricted to one segment of garment sellers, namely, large retail chains (such as Topshop, H\&M and Marks and Spencer), that is, branded garment retailers (Bair and Gereffi, 2003, 147) in two European fashion markets, Sweden and the UK. This study is enhanced by examining the garment manufacturers that branded retailers deal with to some extent in two countries, India and Turkey. In both countries, we find production that provides fashion input from manufacturers' designers that is given to the retailers, and production without any input of design. The idea here is not to conduct a comparative study featuring countries as units; instead, I use the variation to safeguard the generality of the empirical findings at the firm level, which is the unit of analysis.

The empirical evidence draws on several sources of material. I did fieldwork for two months in India, for one month in Turkey, and for much longer in Sweden and in the UK (focusing on Stockholm and London). Participant observation was carried out at factories and garment and fashion fairs. From 2002 to 2004, I conducted twenty-seven interviews with merchandisers, designers, owners and buyers. Most of the interviews and observations took place in India and Turkey, predominately in the areas where the best cultural conditions for designers exist (e.g. New Delhi and Istanbul). 
I have consequently put my ideas to a hard test; if my ideas receive empirical support in these places, we can be certain that they hold true in places that are more remote and have even fewer resources. The lack of resources was in many cases obvious. In an Indian school, to take one example, I was asked to send some fashion magazines from Sweden to be used for educational purposes, which indicates that sometimes there is even lack of information.

The majority of the respondents were theoretically sampled, which means that I traced the chain from a retailer, through a buying office, to its manufacturers. I have also used trade magazines and websites as empirical material, though these sources are only indirectly present in the text. I have visited designer schools and observed classes in both Turkey and India, and have also talked to students at parties. These observations and interactions proved that their perceptions and knowledge of the consumer side, for example of the UK and Sweden, of the industry is rather limited. I spent two months as a visiting scholar at the London College of Fashion, which made it possible to get first-hand knowledge of the work in this highly regarded school. From these experiences, I learned how different perceptions of fashion and design are in different places.

This research design enabled me to identify different kinds of knowledge. The concept of contextual knowledge is the result of the development and differentiation of the initial code 'knowledge' in the empirical material. However, I started out deductively with the idea that 'knowledge' is central, but the more I studied the field, I realized that this concept - as here it relates to upgrading through design-needs qualification. The development of 'contextual' knowledge is consequently the result of an inductive process, guided by the theoretical notion and discussion of 'knowledge'. This means that the interviews and the observations gradually changed into the idea of empirically verifying this hypothesis. Observations and interviews have been strategically combined. For example, observations in garment factories, fairs, shops and designer schools have been pivotal for the questions that I have asked both buyers and sellers in the industry, and also for interpreting and understanding what has been said in the interviews as well as the documents I analyzed. The study, in sum, starts from a theoretical framework and ends with a more developed framework for conceptualizing and understanding knowledge. I use the whole of my material as a background for interpreting the few concrete pieces of evidence I can present here, which reflects the hermeneutical-phenomenological approach of the article. Hence, the validity of the results must be seen in relation to the entire range of material.

\section{Design and markets in the garment industry}

In order to analyze the role of information and knowledge needed by a designer working for a manufacturer who caters to European fashion markets, we must look at the production process of the industry and the conditions facing manufacturers and their designers in developing countries. There are several studies that cover the field of fashion production (Weller, 2007, 40), but few focus on design or the consumer market. The garment industry is tied up in global production chains (e.g. Gereffi, 1994, 1999; Knorringa, 1995; Schmitz and Knorringa, 2000; Bair and Gereffi, 2001; Gibbon, 2001; Kellner, 2002), and the work process has not changed much (Johnson, 1985, 57). Globalization, as used in this article, refers to the way culture, economy, politics and 
other fields are transformed in terms of dependence patterns. While the dependencies that used to exist on the levels of kinship, locality or nation are still important, the impact of globalization has been to augment them gradually by dependencies on the global level.

What happens in the final consumer market of a production chain has repercussions further up the chain. Each retailer has an identity in the final consumer market and a corresponding market niche (White, 2002; Hassler, 2003, 516-517; Aspers, 2008), which specifies the kind of clothes the designer should make (i.e. trousers, shirts, jackets), how much they can cost, and most importantly, how they should look to represent the identity of the firm, and its 'take' on the general fashion trend. The firm's identity is important, as it shapes the type of demand put on its designers. There are of course thousands of brands, but only a fraction of them gain an identity in the sense that they become part of the consumers' cognitive map so that they recognize them, associate something with them, value them and finally are willing to pay a premium to be 'associated' with the identity (cf. the notion of 'brand'; Power and Hauge, 2008). In other words, garments are loaded with meaning in the interaction between the final consumers and the retailer (or brand name), and this gives clothing a social value that differs considerably depending on the position the object holds in the chain (e.g. Slater, 2002, 71-73; Aspers, 2008). It is only when a firm can hold a market niche, which gives it a form of local monopoly based on its identity (cf. White, 2002), that it can make big money, provided that costs can be kept down (Podolny, 2005).

The production process usually begins with design. Retailers' designers are inspired by many things and utilize information from fairs, catwalk shows, local street fashion, films, music videos, art as well as trend analysts and their own experience (cf. McRobbie, 1998; Slater and Tonkiss, 2001, 176-81; Wentig, 2008). In most cases, there is limited design input from the manufacturers with whom branded retailers work. In fact, most garment suppliers are operating according to Tayloristic principles, far from 'aesthetic economies' and 'cultural industries' (cf. Power and Scott, 2004). The following excerpt demonstrates the typical manufacturer-perspective on their role in the design process: 'Most of the time the buyers have their own designers who work on their lines. So they bring us their sketches, and they see what we can offer them'. The task of the manufacturer is to respond with a price, given the quantity, quality, fabrics, shipping and lead time. Today the production cycle of this so-called 'fast fashion' (Barnes and Lea-Greenwood, 2006), from design until the garments can be purchased by consumers, may be as short as 3 weeks, which calls for strong relations between suppliers and their European buyers (cf. Lane and Probert, 2006).

Although designers working for Western retailers create much of what manufacturers produce, some manufacturers have their own fashion lines, and some may work closely also with design. The following representative quote from the head of a manufacturer shows that their fashion line may only be the starting point for a discussion of how the final product should look like: '[if the retailers'] designers ... like some of our work, they can mould them according to their [company's] saleability. They take ideas from our showroom, from our collection and make changes according to their collection, depending on what can sell'. In other words, designers in developing countries contribute to the fashion line that retailers and others sell in developed countries, but this contribution is to a large extent due to the skills of their, rather than their designers' skills (Tewari, 2006, 2336). This contribution is based to some extent on a 'trial and 
error' process, in which the manufacturer gradually learns what a specific buyer wants, and does not represent general knowledge of the market to which its buyers cater. ${ }^{1}$ However, the task of the skilled designer is 'not to just be reactive [to existing trends] but to anticipate and shape consumers trends' (Sunley et al., 2008, 689), which essentially is to offer to the consumers what they not yet know that they will be wanting two months from now. My question, therefore, is: 'how can suppliers upgrade?' To address this issue, one must look closer at the issue of knowledge.

\section{Information and knowledge}

In order to conceptualize the knowledge that designers working for garment retailers in developing countries need, I start by looking at the literature dealing with knowledge. Knowledge must be distinguished from information; information is factual, whereas knowledge is conceptual (cf. Luhmann, [1984] 1995, 67; Amsden, 2001, 3). Amsden's approach suspends the assumption of perfect information, and it is not far-fetched to also challenge the assumption of perfect knowledge, though this does not clarify exactly what knowledge is (cf. Schütz and Luckmann, 1973, I, 106-107).

Researchers have talked of several kinds of knowledge. Giddens' (1984, 375, cf. 328) notion of 'practical consciousness' (cf. implicit knowledge) covers 'what actors know (believe) about social conditions, including especially the conditions of their own action, but cannot express discursively [verbally]'. ${ }^{2}$ He says that implicit knowledge applies to 'rules and tactics whereby daily social life is constituted and reconstituted over time and space' (Giddens, 1984, 90). Bourdieu ([1972] 1977, 2-3) contrasts practical knowledge with forms of theoretical knowledge and argues that the former is embodied in 'habitus, which is constituted in practice' ([1980] 1990, 52; [1997] 2000). The concept of practical knowledge refers mostly to what designers do with their hands. Occasionally, researchers refer to embodied knowledge by using terms such as Fingerspitzengefühl, 'gut-feeling' or 'feel for the game' (Bourdieu, [1980] 1990, 66), but Bourdieu, in the end, stresses the embodied knowledge and lets his notion of field 'explain' how it comes that actions differ between actors. Some have talked of aesthetic knowledge, which refers to the embodied skills of using smell and taste that some practitioners possess (Ewenstein and Whyte, 2007, 289). While these terms give some idea of what is going on, they also mystify and individualize knowledge through the references to the body. Knorr-Cetina's $(1999,8)$ definition of knowledge 'switches the emphasis to knowledge as practiced-within structures, processes and environments that make up "specific" epistemic settings'. This definition points to the non-universal character of knowledge, and it focuses on the context, rather than the individual. I follow her strategy with the notion of contextual knowledge, but attempt to analyze the components of knowledge even further to see how they are related to the social context.

1 So almost regardless of the actual design input, the key matter is how retailers maintain design control over what they put out in the final consumer market. Thus, though design input does exist, as Tokatli et al. $(2008,273)$ report, it is essentially 'buyer controlled'. I am grateful to the reviewer who pointed this out to me.

2 The literature on this field is voluminous and impossible to review completely here (e.g. Rotenstreich, 1977; Crick, 1982; Schatzki et al., 2001; Shapiro et al., 1995; Williams, 2007, 33). 


\section{Contextual knowledge}

Contextual knowledge is defined as having the capacity to 'do what it takes in a situation' (Aspers, 2006b, 746). Contextual knowledge represents an approach to knowledge that avoids both the Nietzschean idea of consciousness as a tool of the body (e.g. 'gut-feeling') and the Cartesian idea of the body as a tool of consciousness (i.e. pure intellectual knowledge). Instead, it focuses on the fact that knowledge must be related to social situations, culture and space as suggested by Knorr-Cetina (cf. Hayek 1945, 521-522; Williams, 2007). This notion means that what is 'knowledge' in a social context cannot be judged independently of those people making up the context, and as such it has both an interpretative and an evaluative aspect. Contextual knowledge, in other words, is only useful in certain contexts (cf. local 'cultures'; Barth, 1995, 66) and is not something that can be transferred from one setting to another like tools since its applicability depends also on other actors, and what they think. This is to say that this knowledge refers to the relation between man and his environment. ${ }^{3}$ The concept implies a further distinction between two elements: the lifeworld and the specific province of meaning, and this distinction will make it easier to see the problems of knowledge in a global market, and point at the spatial dimension of knowledge.

The lifeworld refers to what people take for granted and do not question, such as basic values, propositions, facts, culture and so on. It is something that people living in a culture gradually learn, through socialization, use, 'forget' and eventually take for granted. The lifeworld is composed of culture, institutions and thereby includes concrete values, such as what is beautiful and what is not (Schütz, [1932] 1976, 36, [1966] 1975, 119-120, 131; Berger and Luckmann, [1966] 1995, 13). The lifeworld is the foundation of more theoretical reflections and codified knowledge, and the result of primary (and in many cases secondary) socialization and internalization, and it is therefore deeply rooted. The lifeworld, Schütz ([1966] 1975, 5, 116-132) says, is 'constantly pregiven', and though it is not fixed, it is relatively stable. People can live in different lifeworlds, which are normally anchored to place (e.g. a nation), which is to say that there is a spatial dimension to the distribution of this aspect of knowledge. It is made up of our most taken-for-granted meanings used in the interpretations that people make (cf. Heidegger, [1927] 2001). ${ }^{4}$ This understanding emerges in practical activities, and it is constituted in relation to the lifeworld. We can no more escape our lifeworld than we can escape our spatial positioning. People who share a lifeworld are likely to act and react similarly, and also to make similar kinds of interpretations.

3 See also Haraway's $(1991,2004)$ notion of situated knowledge, which is used by feminist writers (e.g. Enslin, 1994) and refers to epistemology and politics. Indigenous knowledge means 'to make connections between local people's practices and understanding and those of outside researchers and development workers' (Sillitoe, 1998, 224) and is used to promote development. Geertz talks about local knowledge, which includes 'sailing, gardening, politics and poetics' $(1983,167)$, as well as large-scale patterns of thinking such as religion $(1983,234)$. Geertz' sees the law as an example of local knowledge; to have knowledge is to have 'legal sensibility' $(1983,215)$. My point is that one needs knowledge to decode the social structure producing fashion - this is not the equivalent of 'knowing' the law, and it does not refer to the spatial dimension of knowledge.

4 These interpretations are anchored in a distinct time-place structure. This means, if we follow the relational approach (Emirbayer, 1997), that time and space are anchored in cultures; space gets meaning partly because of its culture, in other words, how space is 'cultivated'. 
As not all people living in a lifeworld are able to predict what will be in vogue, contextual knowledge must contain something else.

The second element of contextual knowledge is the province of meaning, which in this case is made up of the 'world of fashion'. The information that designers use comes from different provinces of meaning, and it is ultimately interpreted by designers drawing on their lifeworld. Provinces of meaning have different cognitive styles. Schütz (1962, 230, cf. 1996, 36-38) stresses the cognitive aspects because 'it is our meaning of our experiences and not the ontological structure of the objects which constitutes reality'. Thus, Schütz argues that meaning is constructed in communities or domains (cf. Schütz and Luckmann, 1973, I, 109ff.), which he calls 'finite provinces of meaning' (Schütz, 1962, 230-34). They are finite because there is no formula for transformation between them, such as 'religion', 'science' and 'art'. Fashion, I argue, should be seen as a province of meaning. ${ }^{5}$ One can view fashion as a global phenomenon, in the sense that information about fashion trends is not hard to find. Pictures from catwalks are available a few hours after the show is over, and additional information can be purchased from firms that specialize in analyzing trends, which in one sense make it global. In another sense, however, fashion is local, and tied to nations, cities and subgroups. Each global 'fashion trend' gets a local interpretation, and branded garment retailers operating in a market anchored in space have to relate to what their competitors are doing with these trends, rather than what firms in other markets are doing. Thus, though the production market for fashion garments is global, the consumer market for fashion garment is still essentially local.

Contextual knowledge points at the combination of deeply rooted meaning structures that are the base of interpretation, the dimensions of province of meaning that may be seen as universal with no spatial location, such as fashion trends, and those dimensions that are spatially anchored, such as knowing the competitors and the fashion magazines. Obviously, a person brings 'her' lifeworld along, when she moves between places. It is, hence, the fit between her actions and the context in which these actions are 'evaluated' that determines if she has the capacity to 'do what it takes in a situation'. I will now elaborate on the two components of contextual knowledge of fashion, the fashion province of meaning and the lifeworld, to see how they interact in relation to my empirical material.

\section{Contextual knowledge in the fashion industry}

Why cannot the manufacturers completely take over the design from the branded retailers? The information flow between garment retailers and their manufacturers suggests that there are certain things that manufacturers located in developing countries cannot do. A quote from a manufacturer exemplifies the common perception that buyers, 'help us [by telling us] what kind of product they are looking for', yet it is still not easy to turn this information into a garment that sells. Factory designers do

5 This is not to deny that some actors may know more through 'gossip' than through official channels (cf. White, 2002) about fashion. One can also talk of local differences in fashion, represented, for example, by different national editions of fashions magazines like Elle (in addition to local magazines, cf. Moeran, 2006). 
not lack the skills, or practical-often tacit-knowledge to design. What they lack is the knowledge of what will succeed in the market. As one manufacturer put it when talking about the designs produced by her firm: 'if it doesn't sell—what's the point? They [the buyers] are in the market, they have to be there all the time, and decide what is going to sell and not'. This quotation reflects the situation of the manufacturers I have studied, and suggests that their designers depend on buyers' designer knowledge for guidance. To gain experience, manufacturers depend on the work of buyers' designers, as the following representative comment by a spokesperson of one manufacturer suggests, 'We have designers, but the buyers are also having their designers, so some buyers ask [us to design and develop a fashion line that is only for] their collection. So we develop the collections especially for those customers, country wise, [since] colors change, bodies change'. This suggests that manufactures can at least be tuned in to a specific market, a specific customer and its market niche. This, however, is not enough to replace their buyers' designers, because only the latter 'know' a firm's take on a general fashion trend.

Not the least because, of these problems, buyers have a strong interest in providing manufacturers' designers with relevant information, to increase the likelihood that manufacturers and their designers can provide design input in return. In this process, manufacturers become attuned to the demands of the market (Tokatli and Eldener, 2004) and can learn from the buyers. Thus, some buyers may provide quite detailed information to their manufacturers, but they are less willing to give away information on their whole fashion line, because this is part of the buyer's core field of knowledge (Schmitz and Knorringa, 2000, 201-202). Furthermore, by having many suppliers, perhaps several hundred, each of these suppliers only knows a small part of the bigger picture, which means that the partial insight is not enough to design an entire collection.

Why is contextual knowledge so difficult to acquire? Because, as we have seen, it is a combination of the province of meaning and the more profound lifeworld. I would like to begin with the analysis of the province of meaning. Fashion, to repeat, can be considered a province of meaning with its own logic and 'cognitive style'. Knowledge of this specific province of meaning implies that the actor knows who the players are in her field of fashion, how fashion is diffused, who is wearing what and, above all, what this means for her market. This includes the designer's knowledge about the way fashion is constructed in her market (cf. Entwistle, 2000, 208-236), and about the identity of her firm (i.e. the retailer she designs for) and the identities of competing retailers (cf. White, 2002). She also knows what it takes to reinterpret an upcoming trend for her firm in order to make it different from her competitors' interpretations and their fashion lines. This has been shown by Entwistle. She has studied fashion buyers who purchase clothes to be sold in stores, and the following quote shows how the buying practice is a complicated process in which buyers draw on many sources. The buyer's demand 'came not from objective statistics, such as market research, but forged out the experiential knowledge of the buyer drawing on her own taste culture: indeed her experience as a 'consumer' was as much part of the mix of calculations for the area, as was her identity as a professional buyer' (Entwistle, 2006, 721). The experience from 'being' a consumer in a foreign country is, of course, hard to learn.

Even if designers across the world have access to the same information about fabrics and color trends, they are not likely to interpret it in the same way (cf. Allen, 2002, 44). I suggest that people who work as designers and who can draw on the same background 
as their customers have an advantage, since they 'know' what their customers want. The designer can rely to some extent on her own preferences because she has the same meaning structure as her customers. As a result, she takes many and largely the same things for granted; she shares values, history and ways of thinking with others. This makes it more likely that she will perceive an object, such as a shirt, in a similar way as the final consumers of her work, because she and her customers have been brought up in the same lifeworld. This knowledge, then, is based on their combination of a province of meaning (the fashion world) and the lifeworld of their 'local' home-market.

The fashion that matters to a manufacturer may be very local, perhaps only a single country or even a segment thereof. Thus, statements like 'the trends come from Sweden' by suppliers to Swedish buyers, which in a strict sense are not a correct description of fashion trends of the world, reflect the reality of some suppliers. While the markets are not totally different, the differences are in many cases large enough to make buyers from different countries buy different things, reflecting their different lifeworlds. Retailers may also differentiate their fashion lines, not only among countries, but also among the stores within a country and even between stores in the same city. Thus, a designer in a developing country who is designing for a specific market in a developed country cannot design by simply following general fashion trends. She is, in the words of Simmel, a stranger, who shows detachment from a 'given point in space'. And this is, he continues, '... an indication that spatial relations not only are determining conditions of relationships among men, but are also symbolic of those relationships' (Simmel, [1908] 1971, 143).

The detailed knowledge of the province of meaning that retailers have is not easy to transfer into a codified form (cf. Entwistle, 2006). As a result, suppliers cannot design on their own, since, as they say, 'We do not know the market over there [and] what is going to sell'. Instead, suppliers talk about their relations with buyers as 'big teamwork', or as collaboration, which refers to the dialogue in which the buyer not only tells the manufacturing firm what it wants, but also provides feedback on the manufacturer's different samples. This means that buyers will take ideas from manufactures' showroom, that is, 'from our collection, make changes according to their collection, depending on what can sell', as explained by one manufacturer.

It is important for a designer in this industry to have both the baseline of interpretation that the lifeworld provides and the knowledge of the specific province of meaning of fashion. This province of meaning may be, for example, 'known' through fashion magazines. But the lifeworld that is used to interpret the province of meaning of fashion is harder to 'learn'. Art is one source of inspiration for designers, but in countries like India and Turkey, though the fashion province of meaning is accessible, art galleries are less common. In fact, an art world-defined as a free creativity supported by a number of institutions (Becker, 1982) - is rare in many production countries. Furthermore, the socialization into, as well as later interaction with the art world is important, is thus lacking in many garment production countries. The art they do use is of a rather different kind than what designers of garment sellers in various markets in the West draw on. And more importantly, it is unlikely that the designer in a less developed country, who to some extent is a stranger to the culture in the West, will 'share the same assumptions' (Schütz, 1964, 96). Even with shows known as 'fashion TV', combined with information from business organizations about foreign markets, it would be of little help to instruct an Indian designer to create 
'casual clothing' for the Swedish market if she has never visited that country. So we see again that it is not information per se that is lacking in those working for firms in developing countries that try to upgrade through design.

The visual dimension (cf. Entwistle and Rocamora, 2006, 742-745) also shows the importance of the lifeworld in the role of contextual knowledge. Advertisements, movies, music videos and the 'look' of fashion garments are important dimensions of fashion, because fashion designers use them as sources of inspiration. Understanding the meaning of a picture or seeing it in the same way as someone else does is a result of shared experiences, schooling and other similarities; in short, what Schütz (1964, 161, 177) calls 'growing old together'. Consider the case of a designer dress worn by someone like Rihanna, Victoria Beckham or Madonna at the opening night of a show. The dress is often highly discussed, and often praised, in the fashion and gossip press and, as a result, may affect contemporary fashion. Still, specific interpretations of the dress differ among countries and among competing firms within countries. Again, people are more likely to interpret the meaning of the dress in a similar way when they have both a lifeworld and a province of meaning in common. This observation is supported by the fact that, to my knowledge, no buyers or designers are from production countries, even though the heads of retailers' buying offices, who are less involved in the aesthetic side of fashion production, may indeed be local people. This indicates how difficult it is to perform tasks that are said to demand 'gut-feeling', that is, what I see as contextual knowledge.

Thus, the designer who is not embedded in the lifeworld of the market to which her firm caters will find it difficult to predict what will be in vogue. Manufacturers are usually aware of their problem, as the following excerpt from an interview describes. A head of an Indian manufacturing firm explains what it takes to design for European markets: 'One has to have [high] IQ and an eye to see what people like; it must look nice'. This person, who represents commonly existing perceptions, tends to see design as a capacity that one is either born with or not. Furthermore, he says that one must be able to know how to make a designed item fashionable, such as a shirt. This may not always be easy, and later in the interview he says, 'some of the [garments] that do sell in Europe... I do not understand [them]. I don't like them'. This manufacturer is neither in tune with the lifeworld nor the province of meaning of the market to which he caters, which means that he is not in a good position to upgrade his business by means of design. But '[a]n ability to understand the needs of the client' is exactly what the respondents in the study by Sunley et al. $(2008,686)$ argue 'constitute a good designer'. Thus, if the factory designers do not 'understand' fashion in the same way as their buyers and the final customers do, they are essentially disqualified to design for this market, and consequently, to upgrade through design.

\section{Upgrading strategies}

What strategies can manufacturers use to improve their situation? In some industries, it is sufficient to gain, for example, technological information and then float along by staying up-to-date on the newest technology that suppliers are willing to sell. This approach, however, is inadequate for garment designers and their firms in developing countries who want to sell their products to retailers in the developed world. They must acquire knowledge about both cultural and more concrete fashion changes that take 
place in the markets to which they cater. This means, in other words, that they have to understand the market, almost as hermeneutical philosophers suggest (Gadamer, [1986] 1989).

Upgrading through design and the corresponding competition in Western countries is likely to be the main road for suppliers. But this road, we have shown, is not paved for designers living in places like Hong Kong (Skov, 2002), catering to more high fashion segments. These designers are likely to be seen as instances of the stereotypes produced and maintained in the still Euro-centric fashion world. If manufacturers broaden their focus, they can use other strategies. Manufacturers in developing countries may overcome some problems, such as the issue of contextual knowledge (cf. Schmitz and Knorringa, 2000, 197), by hiring Western designers and seeking out various forms of joint venture. This is a way to upgrade by buying know-how from an expert culture (cf. Amsden, 2001, 238-9, 271; Tokatli, 2007a, 2007b). It is hard to judge how common this practice is, especially since few are willing to talk about it. Some claim that all manufactures 'hire European designers. Either they send them concepts [that they develop together with the Western designer], or she [the designer] comes here two weeks or three weeks and builds up the whole line for them'. In other words, this contextual knowledge is so hard to generate within the organization, that firms spend large sums to hire designers from the countries to which they normally cater. Other manufacturers think that there are some serious problems with hiring designers because, 'when we design a thing, the designer has to think about the merchantability - will it be possible to sell it to the masses?' The designer has to keep in mind, for example, the price range and the skills of the workforce, which determine what the factory can produce and what fabrics it can be use. These aspects, I was told, are not always of prime interest to foreign designers. Thus, although design is a solution for those who want to upgrade, it also adds yet another problem to those that garment manufacturers in developing countries already face (cf. Schmitz and Knorringa, 2000, 2002).

A different strategy for manufacturers is to target their home markets, thereby cutting many costs, including those for information, knowledge and transportation, and thus avoiding the problem of 'contextual knowledge'. The suppliers are probably capable of upgrading and competing in their own countries (Tewari, 2006, 2339-2341), but these markets are still relatively small economically; the problem of upgrading is therefore a derivative problem of the uneven economic development. A correlated strategy is to cater to even less advanced markets. Turkish firms, for example, have used this strategy with the help of a business organization. According to a representative of this organization, these Turkish firms have 'very well-known brands in Russia or in [the] Ukraine... that we have not heard of' (cf. Tokatli and Eledener, 2004; Tokatli, 2007b). Neighboring markets are more likely to resemble the home market, not the least since customers' lifeworlds in these markets often are more similar, as are their interpretations of fashion. This diminishes the problem of contextual knowledge that the firms face. Moreover, marketing is often less costly in developing countries, and for some firms it may be a good way to learn the ropes of the industry in a less competitive environment. However, the lower demands in these markets means that these firms may not automatically meet the often higher demands from global buyers that force the manufacturing firm to increase the quality of its production process. 
To have high-quality production is advantageous when a manufacturer faces buyers. For example, the code of conduct that buyers enforce on their manufacturers may initially be seen, in the eyes of the manufacturers, as a burden, because these codes demand, for example, better working facilities - such as restrooms - for the workers, and they may have to pay sick leave. However, this may change over time, as several of my sources told me, including the head of one manufacturing firm: 'Now we realize the advantages, so it is not only that we are doing it because it is compulsory'. Thus, the manufacturer's competitive edge is sharpened if the firm takes part in the global market competition.

Another strategy is to succumb to making 'knock-off' versions, though one may question if this really is upgrading. Since some of the most 'perishable' garments have a short turnaround time, often as little as $3-5$ weeks, it is not easy to first go to the stores, copy an item and then export it back to the same market in time to still make a profit. Timing is central, and to succeed in the 'fashion business, it is important that you have the goods at the right time; you have to be quick to catch the trains', to quote a representative statement from inside this industry. Therefore, once the copying process is complete, the item may be out of fashion and one cannot get the same added value.

Globalization, emigration, growing diasporas and transnational networks (cf. Crang et al., 2006) do offer one definite advantage, which can overcome some of the problems that manufacturers face, not the least due to their spatial location and the 'problem' that they are rooted in a culture which make it hard to interpret and read the signs of fashion in a way that can be turned into profitable design in the final consumer markets of the wealthy nations. Manufacturers, however, can use personal networks of countrymen who live in Western countries as resource pools of middlemen in their business (cf. Sassen, 2001; Kennedy, 2004), as well as people who travel between the two countries. With the help of these networks, it is possible to have contact persons who live in the final consumer market culture and who can advise manufacturers or know both cultures (cf. Williams, 2007). The following is just one short example of this kind of knowledge transfer: one Indian businessman living in Sweden was the representative of an Indian garment company owned by his brother, who lived in India. He attended trade fairs in Sweden, visited customers regularly and thereby gradually became knowledgeable of the market and customers' demands in Sweden. This knowledge can be used to design clothes that may sell well in the Swedish market. An Indian manufacturer I interviewed, to give a further example of this upgrading strategy, had a business partner of Indian origin based in a Western country. From his very small 'factory' in a residential area (which is illegal), he shipped low fashion garments to overseas customers. Manufacturers can use these kinds of connections and relations to the markets as a stepping-stone toward upgrading the firm by increasing the stylishness and hence the price of the garments. This means that bridges, gradually, can be built between different lifeworlds using personal networks, with the help of social capital. A similar effect can be facilitated by the large number of 'non-European' students in designer schools across Europe, who bring their knowledge back to their countries of origin. There are, in addition, other solutions, such collective action of producers, with our without the support of the state (Lowe, 2009).

Upgrading, as said, implies economic coordination between the firm and its environment, in the form of market, hierarchy or network. I have argued that upgrading through design in the market is hard to accomplish, partly because of the 
structural pattern of trade, which in this industry gives the buyer the upper hand, but partly because of the problem of contextual knowledge. The second form of economic coordination is hierarchy, which would imply the less likely situation that firms in less developed economies start to purchase fashion firms with established brands in Western countries. The most likely form might be to use personal networks as the coordination form to upgrade through design.

\section{Discussion}

The idea of contextual knowledge offers a way to conceptualize the gap across the global market interface between the final consumers and retail designers, on the one hand, and factory designers and the rest of the workforce in garment manufacturing firms in developing countries, on the other. By using the concept of contextual knowledge to handle the specific route to upgrading through design, I do not rely on explanations reduced to either 'cultural difference' (the collectivistic fallacy) or to designers' individual gifts and 'gut-feelings' (the atomistic fallacy). I study what structures knowledge, rather than the embodiment of knowledge, or knowledge as an object. Contextual knowledge refers both to the lifeworld and the province of meaning. Hence, this phenomenologically grounded approach links the cultural, cognitive, social and geographical aspects of knowledge and stresses its interpretative character. This approach to knowledge draws, in addition to phenomenology, on pragmatism and symbolic interactionism, because it is the combined effect of the individual, with her 'knowledge', and the context in which the 'knowledge' is credited that enable us to talk of knowledge and creativity (Mead, 1934, 217); this knowledge is thus like two pieces from a puzzle which are valuable only when they are combined in a certain way. This view of knowledge, which accounts for the 'takenfor-grantedness', is especially useful to understand what goes on in an increasingly global world (Williams, 2007). Moreover, design is very important not only in this industry, but also in the other cultural economy industries that are characterized by aesthetic values. It is likely to become even more vital in the future as aesthetics become more central in the contemporary global society (Lash, 1994; Gronow, 1997; Allen, 2002, 41; cf. Aspers, 2006a).

The knowledge needed to design sellable fashion garments in a consumer market can be divided into two forms. The first is embodied, and or tacit knowledge: sewing, draping and the like, as well as knowledge of how to run a business. Garment manufacturers can, obviously, learn about production techniques and business skills. The second form is contextual knowledge. Knowing what kind of design will be in vogue is not easy for any actor in this industry, and involves quite a bit of gambling. There are no standards to predict whether the product will sell in the market; only the market can tell. It is, put differently, more difficult to learn and transfer knowledge about designing successfully in the garment industry, which is characterized by status orders (Aspers, 2008, 2009), than in industries which are characterized by standard products (cf. Gibbons et al., 1994, 119; Gereffi et al., 2005).

One may be able to accept all that has been said here and still argue that it is no more than a description of the traditional problems firms face when entering new markets. But the fashion garment market, like many markets within cultural industries and outside it with a large element of aesthetic evaluation, is not one in which hard facts 
about the products can persuade the consumer to buy. We are dealing with a problem of a qualitatively new dimension. Even if a firm has the capital to establish itself in a new consumer market, it still must also understand this market - a task that is time-consuming and difficult if one uses one's own meaning structure to interpret what one observes. The power that the buyers have over the producers is of course economic. The power, however, is also symbolic as buyers' interpretations and actions result in the fashion trends that are so important in this industry.

\section{Acknowledgements}

The article has benefited from comments on earlier versions by Jens Beckert, Caroline Dahlberg, Stefanie Hiß, Olga Maletz and Richard Swedberg, and the three JEG reviewers as well as the editor, Neil Wrigley.

\section{References}

Allen, J. (2002) Symbolic economies: the 'culturalization' of economic knowledge. In P. du Gay and M. Pryke (eds) Cultural Economy, Cultural Analysis and Commercial Life, pp. 39-58. London: Sage.

Amin, A. and Thrift, N. (2004) Cultural Economy Reader. Oxford: Blackwell.

Amsden, A. (2001) The Rise of the 'Rest': Challenges to the West From Late-Industrializing Economies. Oxford: Oxford University Press.

Aspers, P. (2006a) Markets in Fashion: A Phenomenological Approach. London: Routledge.

Aspers, P. (2006b) Contextual knowledge. Current Sociology, 54: 745-763.

Aspers, P. (2008) Order in garment markets. ACTA Sociologica, 51: 187-202.

Aspers, P. (2009) Knowledge and value in markets. Theory and Society, 38: 111-131.

Bair, J. and Gereffi, G. (2001) Local clusters in global chains: the causes and consequences of export dynamism in Torreon's blue jeans industry. World Development, 29: 1885-1903.

Bair, J. and Gereffi, G. (2002) NAFTA and the apparel commodity chain: corporate strategies, interfirm networks, and industrial upgrading. In D. Spener, G. Gereffi, J. Bair (eds) Free Trade and Uneven Development. The North American Apparel Industry after NAFTA, pp. 23-50. Philadelphia: Temple University Press.

Bair, J. and Gereffi, G. (2003) Upgrading, uneven development, and jobs in the North American apparel industry. Global Networks, 3: 143-169.

Barnes, L. and Lea-Greenwood, G. (2006) Fast fashioning the supply chain: shaping the research agenda. Journal of Fashion Marketing and Management, 10: 259-271.

Barry, A. and Slater (2005) The Technological Economy. London: Routledge.

Barth, F. (1995) Other knowledge and other ways of knowing. Journal of Anthropological Research, 51: 65-68.

Becker, H. (1982) Art Worlds. Berkeley: University of California Press.

Berger, P. and Luckmann, T. ([1966] 1995) The Social Construction of Reality. New York: Anchor Books.

Bonacich, E. and Applebaum, R. (2000) Behind the Label, Inequality in the Los Angeles Apparel Industry. Berkeley: University of California Press.

Bourdieu, P. ([1972] 1977) Outline of a Theory of Practice. Cambridge: Cambridge University Press.

Bourdieu, P. ([1980] 1990) The Logic of Practice. Cambridge: Polity Press.

Bourdieu, P. ([1997] 2000) Pascalian Meditations. Cambridge: Polity Press.

Burt, R. (1992) Structural Holes: The Social Structure of Competition. Cambridge, MA: Harvard University Press.

Coe, N. M. and Bunnell, T. M. (2003) 'Spatializing' knowledge communities: towards a conceptualization of transnational innovation networks. Global Networks, 3: 437-456.

Crang, P., Dwyer, C., Jackson, P. (eds) (2006) Transnational Spaces. London: Routledge. 
Crick, M. (1982) Anthropology of Knowledge. Annual Review of Anthropology, 11: 287-313.

Currah, A. and Wrigley, N. (2004) Networks of organizational learning and adaptation in retail TNCs. Global Networks, 4: 1-23.

Du Gay P. and Pryke M. (eds) (2000) Cultural Economy, Cultural Analysis and Commercial Life. London: Sage.

Emirbayer, M. (1997) Manifesto for a Relational Sociology. American Journal of Sociology, 103: 281-317.

Enslin, E. (1994) Beyond writing: feminist practice and the limitations of ethnography. Cultural Anthropology, 9: 537-568.

Entwistle, J. (2000) The Fashioned Body: Fashion, Dress and Modern Social Theory. Cambridge: Polity Press.

Entwistle, J. (2002) The aesthetic economy: the production of value in the field of fashion modelling. Journal of Consumer Culture, 2: 317-340.

Entwistle, J. (2006) The cultural economy of fashion buying. Current Sociology, 54: 704-724.

Entwistle, J. and Rocamora, A. (2006) The field of fashion materialized: a study of London fashion week. Sociology, 40: 735-751.

Ewenstein, B. and Whyte, J. (2007) Beyond words: aesthetic knowledge and knowing in organizations. Organization Studies, 28: 689-708.

Gadamer, H. G. ([1986] 1989) Truth and Method. 2nd. Rev. edn., New York: Continuum.

Geertz, C. (1983) Local Knowledge: Further Essays in Interpretative Anthropology. New York: Basic Books.

Gereffi, G. (1994) The organization of buyer-driven global commodity chains: how U.S. retailers shape overseas production networks. In G. Gereffi and M. Korzeniewics (eds) Commodity Chains and Global Capitalism, pp. 95-123. Westport: Praeger.

Gereffi, G. (1999) International trade and industrial upgrading in the apparel commodity chain. Journal of International Economics, 48: 37-70.

Gereffi, G., Humphrey, J., Sturgeon, T. (2005) The governance of global value chains. Review of International Political Economy, 12: 78-104.

Gertler, M. (2003) Tacit knowledge and the economic geography of context, or the undefinable tacitness of being (there). Journal of Economic Geography, 3: 75-99.

Gibbon, P. (2001) Upgrading primary production: a global commodity chain approach. World Development, 29: 345-363.

Gibbons, M. et al. (1994) The New Production of Knowledge: The Dynamics of Science and Research in Contemporary Societies. London: Sage.

Giddens, A. (1984) The Constitution of Society: Outline of the Theory of Structuration. Berkeley: University of California Press.

Giuliani, E. (2007) The selective nature of knowledge networks in clusters: evidence from the wine industry. Journal of Economic Geography, 7: 139-168.

Giuliani, E., Pietrobelli, C., Rabellotti, R. (2005) Upgrading in global value chains: lessons from Latin American clusters. World Development, 33: 549-573.

Gronow, J. (1997) The Sociology of Taste. London: Routledge.

Harraway, D. ([1991] 2004) Situated knowledge: the science question in feminism and the privilege of partial perspective. In S. Harding (ed.) The Feminist Standpoint Theory Reader, Intellectual and Political Controversies, pp. 81-102. London: Routledge.

Hassler, M. (2003) The global clothing production system: commodity chains and business networks. Global Networks, 3: 513-531.

Hauge, A. (2007) Dedicated Followers of Fashion, An Economic Geographic Analysis of the Swedish Fashion Industry. Uppsala: Uppsala University.

Hayek, F. (1945) The use of knowledge in society. The American Economic Review, 35: 519-530.

Heidegger, M. ([1927] 2001) Sein und Zeit. Tübingen: Max Niemeyer.

Humphrey, J. and Schmitz, H. (2002) How does insertion in global value chains affect uppgrading in industrial cluster. Regional Studies, 36: 1017-1027.

Johnson, M. (1985) Postwar industrial development in the Southeast and the pioneer role of labor-intensive industry. Economic Geography, 61: 46-65.

Kawamura, Y. (2006) Japanese teens as producers of street fashion. Current Sociology, 54: 784-801.

Kellner, D. (2002) Theorizing globalization. Sociological Theory, 20: 285-305. 
Kennedy, P. (2004) Making global society: friendship networks among transnational professionals in the building design industry. Global Networks, 4: 159-179.

Kloosterman, R. (2008) Walls and bridges: knowledge spillover between 'superdutch' architectural firms. Journal of Economic Geography, 8: 545-563.

Knorr-Cetina, K. (1999) Epistemic Culture: How the Sciences Make Knowledge. Cambridge: Harvard University Press.

Knorringa, P. (1995) Economics of Collaboration in Producer-Trader Relations: Transaction Regimes Between Markets and Hierarchy in the Agra Footwear Cluster, India. Doctoral Dissertation. Den Haag: CIP-DATA, Koninklijke Bibliotheek.

Knorringa, P. (2002) Cluster trajectories and the likelihood of endogenous upgrading. In P. Van Dijk and H. Sandee (eds) Innovation and Small Enterprises in the Third World, pp. 48-65. Cheltham: Edward Elgar.

Korzeniewics, M. (1994) Commodity chains and marketing strategies: Nike and the global footwear industry. In G. Gereffi and M. Korzeniewics (eds) Commodity Chains and Global Capitalism, pp. 247-266. Westport: Praeger.

Lane, C. and Probert, J. (2006) Domestic capabilities and global production networks in the clothing industry: a comparison of German and UK firms' strategies. Socio-Economic Review, 4: $35-67$.

Lash, S. (1994) Reflexivity and its doubles: structure, aesthetics, community. In U. Beck, A. Giddens, S. Lash (eds) Reflexive Modernization, Politics, Tradition and Aesthetics in the Modern Social Order, pp. 110-173. Cambridge: Polity Press.

Lowe, N. (2009) Challenging tradition: unlocking new paths to regional industrial upgrading. Environment and Planning A, 41: 128-145.

Luhmann, N. ([1984] 1995) Social Systems. Stanford, CA: Stanford University Press.

Maskell, P. and Malmberg, A. (2007) Myopia, knowledge development and cluster evolution. Journal of Economic Geography, 7: 603-618.

McRobbie, A. (1998) British Fashion Design: Rag Trade or Image Industry? London: Routledge.

Mead, G. (1934) Mind, Self, and Society, From the Standpoint of a Social Behaviorist. Chicago: Chicago University Press.

Moeran, B. (2006) More than just a fashion magazine. Current Sociology, 54: 725-744.

Palpacuer, F., Gibbon, P., Thomsen, L. (2005) New challenges for developing country suppliers in global clothing chains: a comparative European perspective. World Development, 33: 409-430.

Palpacuer, F. and Parisotto, A. (2003) Global production and local jobs: can global enterprise networks be used as levers for local development. Global Networks, 3: 97-120.

Peters, E., Durán, R., Piore, M. (2002) Learning and the limits of foreign Partners as teachers. In D. Spener, G. Gereffi, J. Bair (eds) Free Trade and Uneven Development. The North American Apparel Industry after NAFTA, pp. 224-225. Philadelphia: Temple University Press.

Podolny, J. (2005) Status Signals, A Sociological Study of Market Competition. Princeton, NJ: Princeton University Press.

Power, D. (2002) "Cultural Industries" in Sweden: an assessment of their place in the Swedish economy. Economic Geography, 78: 103-127.

Power, D. and Hauge, A. (2008) No man's brand - brands, institutions, fashion and the economy. Growth and Change, 39: 123-143.

Power. D., Scott, A. (2004) The Cultural Industries and the Production of Culture. London: Routledge.

Rothenstreich, N. (1977) Theory and Practice: An Essay in Human Intentionalities. The Hague: Martinus Nijhoff.

Sassen, S. (2001) The Global City. New York; London; Tokyo; Princeton: Princeton University Press.

Schatzki, T., Knorr Cetina, K., Savigny, E. von (eds) (2001) The Practice Turn in Contemporary Theory. London: Routlege.

Schmitz, H. and Knorringa, P. (2000) Learning from global buyers. The Journal of Development Studies, 37: 177-204.

Schrank, A. (2004) Ready-to-wear development? Foreign investment, technology transfer, and learning by watching in the apparel trade. Social Forces, 83: 123-156. 
Schütz, A. ([1932] 1976) The Phenomenology of the Social World. London: Heineman Educational Books.

Schütz, A. (1962) Collected Papers I: The Problem of Social Reality. The Hague: Nijhoff.

Schütz, A. (1964) Collected Papers II: Studies in Social Theory. The Hague: Nijhoff.

Schütz, A. ([1966] 1975) Collected Papers III: Studies in Phenomenological Philosophy. The Hague: Nijhoff.

Schütz, A. (1996) Collected Papers IV. Dordrecht: Kluwer Academic Publishers.

Schütz, A. and Luckmann, T. (1973) The Structures of the Lifeworld. Two Volumes. Evanston: Northwestern University Press.

Shapiro, I. and Wagner De Cew, J. (eds) (1995) Theory and Practice. New York: New York University Press.

Sillitoe, P. (1998) The development of indigenous knowledge: a new applied anthropology (in anthropology and the indigenous). Current Anthropology, 39: 223-252.

Simmel, G. ([1908] 1971) "The Stranger". In D. Levine (ed.) George Simmel on Individuality and Social Form, pp. 143-149. Chicago: Chicago University Press.

Skov, L. (2002) Hong Kong fashion designers as cultural intermediaries: out of global garment production. Cultural Studies, 16: 553-569.

Skov, L. (2003) Fashion-nation: a Japanese globalization experience and a Hong Kong dilemma. In C. Jones, A. Leshkowich, S. Niessen (eds) Re-Orienting Fashion: The Globalization of Asian Fashion, pp. 215-242. Oxford: Berg.

Slater, D. (2002) Capturing markets from the economists. In P. du Gay and M. Pryke (eds) Cultural Economy, Cultural Analysis and Commercial Life, pp. 59-77. London: Sage.

Slater, D. and Tonkiss, F. (2001) Market Society, Markets and Modern Social Theory. Cambridge: Polity Press.

Sunley, P. et al. (2008) Innovation in a creative production system: the case of design. Journal of Economic Geography, 8: 675-698.

Swidler, A. and Arditi, J. (1994) The new sociology of knowledge. Annual Review of Sociology, 20: 305-329.

Tewari, M. (2006) Adjustment in India's textile and apparel industry: reworking legacies in a post-MFA world. Environment and Planning A, 38: 2325-2344.

Thomsen, L. (2007) Accessing global value chains? The role of business-state relations in the private industry in Vietnam. Journal of Economic Geography, 7: 753-776.

Tokatli, N. (2007a) Networks, firms, and upgrading within the blue-jeans industry: evidence from Turkey. Global Networks, 7: 51-58.

Tokatli, N. (2007b) Assymetrical relations and upgrading among suppliers of clothing brands: Hugo Boss in Turkey. Journal of Economic Geography, 7: 67-92.

Tokatli, N. and Eldener, Y. B. (2004) Upgrading in the global clothing industry: the transformation of Boyner holding. Competition and Change, 8: 173-193.

Tokatli, N., Wrigley, N., Kizilgün, Ö. (2008) Shifting global supply networks and fast fashion: made in Turkey for Marks \& Spence. Global Networks, 8: 261-371.

Weller, S. (2007) Fashion as viscous knowledge: fashion's role in shaping trans-national garment production. Journal of Economic Geography, 7: 39-66.

Wenting, R. (2008) Spinoff dynamics and the spatial formation of the fashion design industry, 1885-2005. Journal of Economic Geography, 8: 593-614.

White, H. (1970) Chains of Opportunity: System Models of Mobility in Organizations. Cambridge, MA: Harvard University Press.

White, H. (2002) Markets from Networks: Socioeconomic Models of Production. Princeton: Princeton University Press.

Williams, A. (2007) International labour migration and tacit knowledge transaction: a multi-level perspective. Global Networks, 7: 29-50. 